Supporting Information for

\title{
Microalgae Harvesting by Self-Driven 3D Microfiltration with Rationally Designed Porous Superabsorbent Polymer (PSAP) Beads
}

\author{
Wensi Chen ${ }^{1}$, Ting Wang ${ }^{1}$, Zeou Dou ${ }^{1}$, Xing Xie X,2* $^{1,2}$ \\ ${ }^{1}$ School of Civil and Environmental Engineering, Georgia Institute of Technology, Atlanta, \\ Georgia 30332, United States \\ ${ }^{2}$ Institute for Electronics and Nanotechnology, Georgia Institute of Technology, Atlanta, Georgia \\ 30332, United States \\ *Corresponding Author, E-mail: xing.xie@ce.gatech.edu
}

\section{Summary}

Number of pages: 4 (S1-S4)

Number of figures: 4 (Figures S1-S4)

Number of tables: 2 (Tables S1-S2) 


\section{Additional Figures}

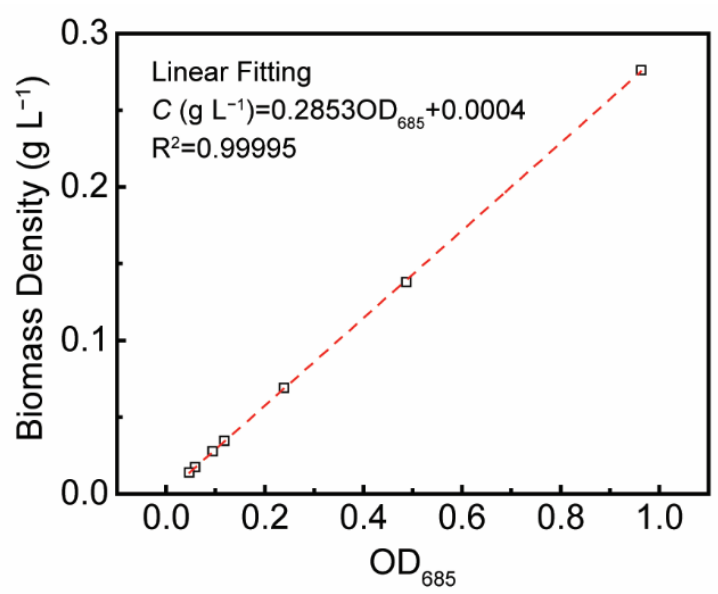

Figure S1. Correlation between optical density at $685 \mathrm{~nm}$ and microalgal biomass density (dry cell weight). The biomass density was measured by filtering $25 \mathrm{~mL}$ of microalgal suspension through a microfiltration membrane filter $(0.2 \mu \mathrm{m}$ pore size $)$. The loaded filter was dried at $60^{\circ} \mathrm{C}$ until the weight is invariant. The weight of the blank filter was subtracted from that of the loaded filter to calculate the dry cell weight of microalgae.
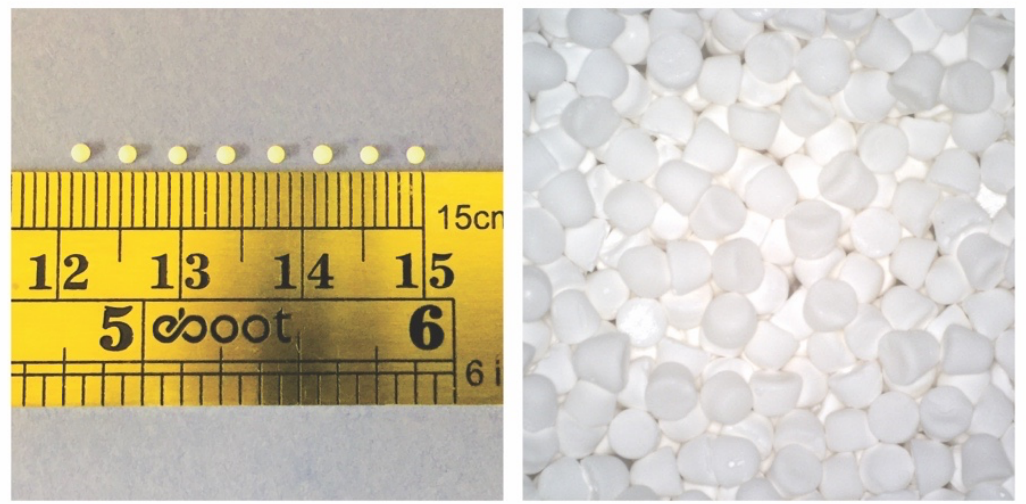

Figure S2. Optical images of the PSAP beads. The dried PSAP products are white-colored with an average diameter of around $1.5 \mathrm{~mm}$. 

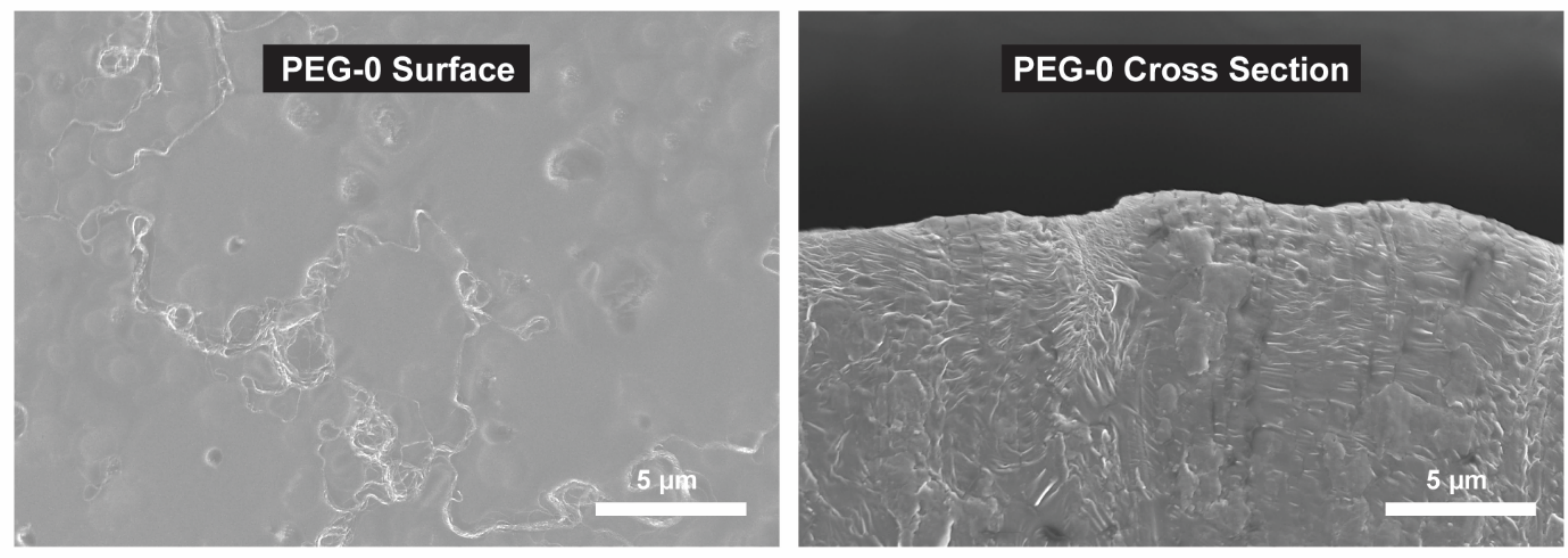

Figure S3. SEM images of the SAP beads. The SAP beads were prepared by the precursor without the addition of porogen (PEG).

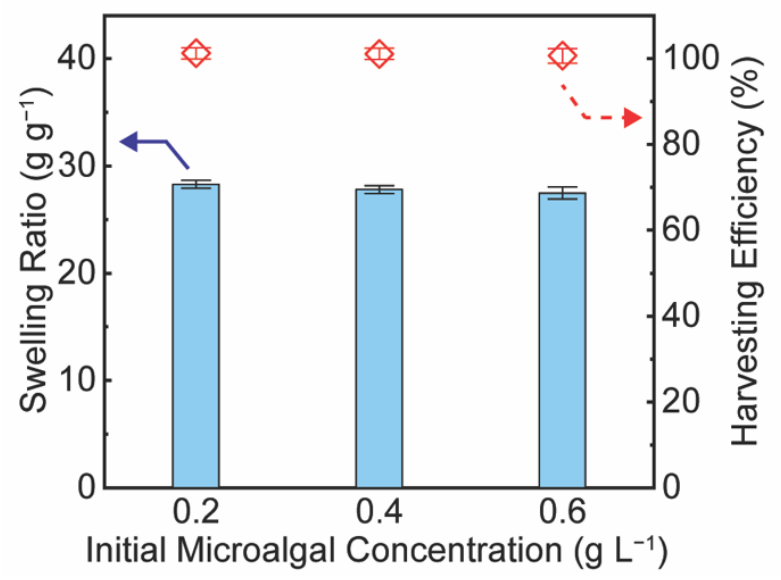

Figure S4. Microalgae harvesting performance of the SAP beads. The SAP dosage was around 8 $\mathrm{g} \mathrm{L}^{-1}$ and the treatment time was set at $30 \mathrm{~min}$. The final concentration factor was around 1.3 when the initial microalgal concentration was in range of $0.2-0.6 \mathrm{~g} \mathrm{~L}^{-1}$. 


\section{Additional Tables}

Table S1. The composition of BG-11 medium for microalgae cultivation.

\begin{tabular}{cccc}
\hline Compound & $\begin{array}{c}\text { Concentration } \\
(\mathrm{mM})\end{array}$ & Compound & $\begin{array}{c}\text { Concentration } \\
(\mathrm{mM})\end{array}$ \\
\hline $\mathrm{H}_{3} \mathrm{BO}_{3}$ & 46 & $\mathrm{NaNO}_{3}$ & 0.23 \\
$\mathrm{MnCl}_{2} \cdot 4 \mathrm{H}_{2} \mathrm{O}$ & 9 & $\mathrm{~K}_{2} \mathrm{HPO}_{4}$ & 0.3 \\
$\mathrm{ZnSO}_{4} \cdot 7 \mathrm{H}_{2} \mathrm{O}$ & 0.77 & $\mathrm{MgSO}_{4} \cdot 7 \mathrm{H}_{2} \mathrm{O}$ & 0.24 \\
$\mathrm{Na}_{2} \mathrm{MoO}_{4} \cdot 2 \mathrm{H}_{2} \mathrm{O}$ & 1.6 & $\mathrm{CaCl}_{2} \cdot 2 \mathrm{H}_{2} \mathrm{O}$ & 0.031 \\
$\mathrm{CuSO}_{4} \cdot 5 \mathrm{H}_{2} \mathrm{O}$ & 0.3 & $\mathrm{Citric} \mathrm{Acid}_{2} \mathrm{H}_{2} \mathrm{O}$ & 0.021 \\
$\mathrm{Co}\left(\mathrm{NO}_{3}\right)_{2} \cdot 6 \mathrm{H}_{2} \mathrm{O}$ & 0.17 & Ferric Ammonium Citrate & 0.0027 \\
$\mathrm{NaNO}_{3}$ & 17.6 & $\mathrm{Na}_{2}$ EDTA $2 \mathrm{H}_{2} \mathrm{O}$ & 0.19 \\
\hline
\end{tabular}

The as-prepared BG-11 medium had a pH of 7.76 and conductivity of $2360 \mu \mathrm{S} \mathrm{cm}^{-1}$.

Table S2. Cost analysis of microalgae harvesting by PSAP beads.

\begin{tabular}{ccccc}
\hline $\begin{array}{c}\text { Initial Microalgal } \\
\begin{array}{c}\text { Concentration } \\
\left(\mathrm{g} \mathrm{L}^{-1}\right)\end{array}\end{array}$ & $\begin{array}{c}\text { PSAP Dosage } \\
\left(\mathrm{g} \mathrm{L}^{-1}\right)\end{array}$ & $\begin{array}{c}\text { Concentration } \\
\text { Factor }\end{array}$ & $\begin{array}{c}\text { Harvesting } \\
\text { Efficiency } \\
(\%)\end{array}$ & $\begin{array}{c}\text { PSAP Cost }^{\mathrm{a}} \\
\left.\text { (USD m }^{-3}\right)\end{array}$ \\
\hline 0.2 & 8 & 2.3 & $>95$ & 1.4 \\
0.2 & 12 & 4.8 & $>95$ & 2.1 \\
0.2 & 17 & 10 & 94 & 3.0 \\
0.2 & 18 & 13 & 90 & 3.2 \\
$1-25$ & 8 & 2.2 & $>95$ & 1.4 \\
50 & 8 & 2 & $>95$ & 1.4 \\
70 & 8 & 1.8 & $>95$ & 1.4 \\
\hline
\end{tabular}

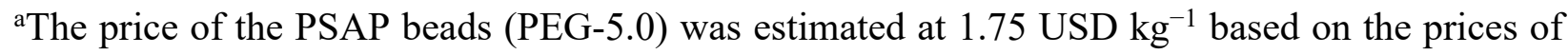
the commercial SAP beads $\left(\sim 1 \mathrm{USD} \mathrm{kg}^{-1}\right)$ and porogen $\left(\sim 1.5 \mathrm{USD} \mathrm{kg}^{-1}\right.$ for PEG). The PSAP beads were assumed to be used with regeneration for ten times. Thus, the average cost of the PSAP beads could be as low as $0.175 \mathrm{USD} \mathrm{kg}^{-1}$ for each treatment. The regeneration cost was not considered in the cost analysis. Therefore, the material cost to treat each cubic meter of microalgal suspension was calculated by: PSAP cost $\left(\mathrm{USD} \mathrm{m}^{-3}\right)=$ PSAP dosage $\left(\mathrm{g} \mathrm{L}^{-1}\right) \times$ PSAP unit price (USD kg-1). 